ÖĞRENCILERIN YAZILI ANLATIM ÇALIŞMALARININ TÜRKÇE

ÖĞRETMENLERINCE DEĞERLENDİRILMESI ÜZERINE ${ }^{1}$

\title{
ON EVALUATION WRITTEN EXPRESSION STUDY OF STUDENTS BY THE TURKISH TEACHERS
}

\section{Ali GÖÇER*}

ÖZET: Bu çalışmanın amacı, öğrencilerinin yazılı anlatım çalı̧malarımın değerlendirilmesinde Türkçe öğretmenlerinin uyguladıkları değerlendirme biçimlerini tespit etmektir. Araştırmada nitel araştırma yaklaşımı kapsamında 12 Türkçe öğretmeni ile görüşme yapılmıştır. Ayrıca Türkçe öğretmenlerinin öğrencilerine yazdırdıkları etkinlik içi yazma dokümanlar ile uyguladıkları yazılı sınav kâğıtlar da doküman olarak incelenmiştir. Araştırmada ulaşılan bulgulara göre, Türkçe öğretmenleri, yazıll sinavda sorulan kompozisyon sorusunun öğrencilerin yazılı anlatım becerilerini tam olarak yansitmadığını ileri sürmektedirler. Bunun sebebinin de Türkçe sinavlarmnn diğer sorularla birlikte kompozisyon sorusuna 40 dakikalık bir süre verildiğini ve tüm sorularla birlikte kompozisyon yazmalarına yeterli zaman kalmadığın belirtmektedirler. Yazılı anlatım çalışmaların değerlendirirken her bir öğretmenin farklı ölçütlerle değerlendirme yaptı̆̆ı, tüm öğretmenlerin kullandığı genel bir ölçüt birliğinin olmadığı görülmmüştür. Ayrıca, yazılı anlatım çalışmalarının değerlendirilmesinde biçimsel özellikler içerik özelliklerinden daha ön planda tutulmaktadır.

Anahtar sözcükler: Türkçe eğitimi, İlköğretim ikinci kademe, Yazılı anlatım ve değerlendirme.

\footnotetext{
${ }^{1}$ Bu makale, 25-28 Eylül 2010 tarihlerinde Bilkent Üniversitesi ve Sofya St. Kliment Ohridski Üniversitesi işbirliğiyle Kırcaali-Bulgaristan'da düzenlenen $V$. Uluslararası Büyük Türk Dili Kurultayı'nda sunulan bildiri temel alınarak oluşturulmuştur.

* Dr. Ali GÖÇER, Erciyes Üniversitesi, Eğitim Fakültesi, Türkçe EğitimiBölümü, aligocer@windowslive.com.
} 
ABSTRACT: The purpose of this study, to determine Turkish teachers' application and their evaluation forms. In this research, were interviewed 12 Turkish teachers in the context of qualitative research approach. Moreover, the activities of students write their applications in writing with documents written examination papers or documents as are investigated. According to the findings in the study reach, Turkish teachers, writing essay exam questions asked in the written narrative skills of the students, does not reflect exactly are adduced. The reason that the composition of the Turkish exam questions with other questions were given 40 minutes and all questions with enough time left to write compositions are indicated. Written expression when assessing the work of each teacher is evaluated by different criteria, all the teachers' union was not a general criterion. In addition, are kept more foreground formal features from content features in the evaluation of written expression studies.

Key Words: Turkish education, primary education second grade, writing and evaluation

\section{GİRIŞ}

Dil eğitimi, dört temel dil becerisi üzerine gerçekleştirilen çalışmalarla yürütülmektedir. Bu eğitim sürecinde bireylere kazandırılması hedeflenen becerilerden birisi de yazma becerisidir. Okullarda öğrencilere bu beceriyi kazandırmak amacıyla değişik çalışmalar yapılmaktadır. Yazma çalışmaları amaçlı bir eğitim etkinliğidir. Konu seçiminden ortaya çıkan ürünün değerlendirilmesine kadar dinamik bir süreci gerekli kılar (Göçer, 2010: 273). Bireyler herhangi bir olay ya da durumla ilgili olarak duygu, düşünce, tasarı, izlenim ve hayallerini yazı aracılığı ile ortaya koyarlar. Yazılı anlatım çalışmalarıyla öğrencilerin günlük yaşamlarını kolaylaştıracak belli bir düzeyde anlatım ve ifade gücü kazanmaları hedeflenmektedir. İlköğretimde öğrencilere anlatma öğrenme alanı çerçevesinde yazma becerisinin geliştirilmesine yönelik kazanımlar belirlenmiş ve öğrencilerin bu kazanımlara ulaşabilmeleri için etkinlikler önerilmiştir. Öğrencilerin yazılı anlatım becerisi ve buna dayalı olarak bazı üst düzey becerileri kazanmaları için temel gereksinimdir. Bu üst düzey becerilerden en önemlisi iletişim becerisidir. Yazılı anlatım ise insanların birbirleriyle kurdukları iletişimin en önemli ve vazgeçilmez aracıdır. 
Türkçe dersinde yapılan yazılı sınavlarda yer verilmesi gereken sorular üç ana kategoriden oluşmaktadır. Bunlardan birisi, öğrencilerin bir konu hakkında duygu, düşünce, hayal, tasarı ya da izlenimlerini anlatmalarına ortam hazırlayan kompozisyon sorusudur (Göçer, 2009: 401). Millı̂ Eğitim Bakanlığı 1747 Sayılı Tebliğiler Dergisinde kompozisyon sınavlarının bir seviye değerlendirmesi olduğunu vurgulanmakta ve şöyle denilmektedir: Öğrencilerin, programın öngördüğü seviyeye gelebilmeleri ve dil bilgisine en çok başvurmayı gerektiren alan kompozisyon olduğu için en az okuma ve dil bilgisi kadar üzerinde durulması gerekir (MEB, 1973).

Yazı oluşturma (kompozisyon) süreci son derece karmaşık bir süreçten oluşmaktadır (Witte and Faigley, 1981: 202). Kompozisyon süreci, yazılan konunun içeriğini bilme, içeriği işlemeye yarayan süreç bilgisi, yazı türünü belirleyen plan, sözdizimsel formları ve noktalama işaretlerinin kullanımını kapsayan yazı üretme bilgisini uygulama (Hillocks, 1987: 71) aşamalarından oluşur. Bu süreç sadece yazma aktivitesi değil, aynı zamanda dil bilgisi, analiz, söz sanatlarını kullanma vb. çalışmaları içine alan, birbirinden bağımsız yazma öncesi etkinlikleriyle yeniden yazma etkinliğinden oluşur (Zamel, 1982: 196). Emig, kompozisyon yazarken öğrenciler yazmanın doğrusal olmayan doğasını gösteren çeşitli davranışlar gösterirler. Bu yüzden yazı yazmayı/yazı oluşturmayı öğreten öğretmenlerin kompozisyon oluşturma sürecini hafife almalarının, eksik kavramsallaştırma yapmalarının yanlışlığını vurgular (1971: 98). Bu sürecin temel özelliği tekrarlama, taslak oluşturma ve gözden geçirme gibi birbirleriyle etkileşim içinde olan aşamalardan oluşmasıdır (Murray, 1980: 4-5).

Taylor, yaptığı araştırma ve yapılan çalışmalardan hareketle yazma öğretiminde gördüğü şu üç temel soruna dikkat çekmektedir: 1 . Öğrencilere yazıyı bir keşfetme süreci olarak kullanmaktan ziyade tamamen plan ve taslak öğretmek. 2. Gözden geçirmeyi yazıyı güçlü kılma aracı olmaktan çok mekanik bir redaksiyon işi olarak (görmek) öğretmek. 3. Öğrencilere düzenlemenin, düşüncelerin ve anlamın dişında gelişebileceğinden çok fikirlerini önceden var olan modellere uygulamayı öğretmek (1981: 8). Öğretmenler, öğrencilerine yazma becerisini kazandırmak için temel teorik bilgileri kavrattıktan sonra değişik materyaller eşliğinde farklı çalışma ortamları hazırlamalı, öğrencilerin özgün ürünler ortaya koyabilmeleri için farklı etkinlikler 
düzenlemelidirler. Bu konuda Skandalaris, öğrencilerin düşüncelerini yazıya dökmelerine hazırlamak ve buna yoğunlaşmalarını sağlamak için öğretmenin öğrencilerle diyalog yapmasının ve (yeni ve farklı) fikirlere açık olmasının önemini vurgulamaktadır (1998: 3). Taylor da sınıf içi tartışmalar yoluyla yapılabilecek sözel beyin fırtınaları, öğrencilerin düşünceler arasında ilişkilendirmeler ve genellemeler yapmalarına zemin oluşturabileceğini belirtmiştir (1981: 10). Yazma öncesi öğrencileri yazıya hazırlama ve yazma sonrası yapılan çalışmalarla ilgili geribildirimde bulunma öğretmenlerin ihmal etmemesi gereken etkinliklerdir. Smith'e göre yazılı anlatım becerisi, okuma ve yazma yoluyla öğrenilir, diyalog ve tartışma ile geliştirilebilir. Diğer insanlarla konuşmak bir bakıma yazmak gibidir ve insanın fikirlerini ortaya dökmesini ve yenilerine sahip olmasını sağlar (1994: 207).

Değerlendirme etkinliği, öğrenme-öğretme sürecinin çok önemli bir parçasıdır. Eğitim öğretim sürecinin ne derece işlediği, öğrencilerin beceri ve kazanımlara ulaşıp ulaşamadıklarının belirlenebilmesi için hem öğrencilerin hem de öğretmenin, süreç boyunca değerlendirme faaliyeti yürütmesi gerekir. Diğer dil becerilerinde olduğu gibi yazma becerisinde de değerlendirme çalışmaları çeşitli biçimlerde yapılmaktadır. Yazılı anlatım çalışmalarının ölçülmesinde çeşitli ölçekler kullanılabilir. (Örnek ölçek için bkz. EK 1 a ve $1 b)$.

1611 sayılı Tebliğler Dergisinde Türkçe sınavlarına ilişkin yayımlanan genelgede yazılı anlatımın değerlendirilmesi hususunda şu ifadeler yer almaktadır (MEB, 1970): “Kompozisyon çalışmalarının amacı, öğrencilerin belli yerlerde ve zamanlarda değil, hayatın bütün etkinliklerinde gerektiği gibi anlatma, yazma gücü ve alışkanlıklarını kazanmaları olduğuna göre, not bareminde en aşağı \% 40 verilmesi istenen yazılı anlatım değerlendirilirken yalnız "Kompozisyon" sorusunun cevabı değil; belli bir oranda imtihan kâğıdının bütünü, söz dizimi, imla, noktalama, anlatım açılarından değerlendirilmelidir.

Değerlendirme nasıl yapılırsa yapılsın çocuğun kendine olan güveninin sarsılmaması gerekir. Okurer'e (1967: 73) göre, bir yazı hem teknik-form tarafı hem de muhteva-fikir tarafı ile birlikte bir değer ifade eder. Teknik (şekle ait) yanlış ile konunun işlenmesine dair yapılan yanlışları ayrı değerlendirmek gerekir. Yani imla hataları ile çocuğun zihnî kabiliyetlerinin gelişmemesinden, olgunlaşmamasından ileri gelen noksanların birbirinden ayrılması gerekir. 


\section{ARAȘTIRMANIN AMACI}

$\mathrm{Bu}$ araştırma ile ilköğretim öğrencilerinin yazılı anlatım çalışmalarının değerlendirilmesinde Türkçe öğretmenlerinin uyguladıkları yöntem ve teknikleri belirlemektir. Bu amaçla, Türkçe öğretmenlerinin ders işlenişi sırasında öğrencilerine yaptırdıkları yazılı anlatım çalışmaları ile yazılı sinavlarda sordukları kompozisyon sorusuna karşılık olarak öğrencilerin oluşturdukları metinlerin değerlendirilmesinde göz önünde bulundurdukları ölçütler belirlenmeye çalışılmıştır.

\section{YÖNTEM}

Türkçe öğretmenleriyle yapılan görüşmeler sonucunda öğrencilerin yazılı anlatım çalışmalarının değerlendirilmesinin genel bir görünümü verilmeye çalışılmış, elde edilen sonuçlar ışığında birkaç öneri sunulması amaçlanmıştır.

\section{1. Araştırmanın modeli}

Araştırmada, nitel araştırma yaklaşımı çerçevesinde durum belirleme amacina yönelik olarak görüşme ve doküman inceleme yöntemleri kullanılmıştır. Temel veri toplama aracımız olan görüşme formu ile elde edilen veriler içerik analizine tabi tutulmuştur. Doküman olarak toplanan yazılı sınav kâğıtları tarama tekniği ile incelenmiştir. Görüşme formları ve yazılı sınav kâğıtları öğrencilerin kompozisyon kâğıtlarının değerlendirilmesi uygulamaları belirlenmeye çalışılmıştır. Veri toplama araçları ile ulaşılan bulgular doğrultusunda birtakım sonuç ve öneriler ortaya konulmuştur.

\section{2. Evren ve örneklem}

$\mathrm{Bu}$ araştırmanın evrenini Kayseri ili Melikgazi ilçesindeki ilköğretim okullarında görev yapan Türkçe öğretmenleri oluşturmaktadır. Söz konusu ilçenin farklı sosyo kültürel çevresinde (Merkez ve kenar mahallelerde) yer alan altı okul tabakalama örnekleme yöntemiyle belirlenmiştir. Belirlenen okullarda görev yapan 12 Türkçe öğretmeni araştırmanın örneklemini oluşturmaktadır. Ayrıca, incelenmek üzere Türkçe öğretmenlerinin etkinlik içi uyguladıkları yazılı anlatım çalışmaları ile yaptıkları yazılı sınav kâğıtlarından alınan örnekler de incelenmek üzere belirlenmiştir. 


\subsection{Sinırlılıklar}

$\mathrm{Bu}$ araştırma, görüşme yapılan 12 Türkçe öğretmeni, veri toplama aracı olarak kullanılan görüşme formundaki 7 (yedi) görüşme sorusu ve öğretmenlerin görüşme sorularına verdikleri cevaplar, yaptıkları etkinlik için yazılı anlatım dokümanları ile uyguladıkları yazılı sınav kâğıtları verileriyle sinırlıdır.

\section{4. Verilerin toplanması ve analizi}

Araştırmada, nitel araştırma yaklaşımı çerçevesinde görüşme yöntemi kullanılmıştır. Veri toplama aracı olarak yarı yapılandırılmış görüşme formu hazırlanmıştır. Hazırlanan form öncelikle iki Türkçe öğretmenine uygulanmış ve alınan cevaplar doğrultusunda görüşme formuna son şekli verilmiştir. Daha sonra yedi sorudan oluşan görüşme formu örneklem olarak belirlenen 12 Türkçe öğretmenine uygulanmıştır. Görüşme ile elde edilen veriler içerik analizine tabi tutulmuş, toplanan dokümanlar ise tarama tekniği ile incelenmiştir.

İçerik analizi, birbirine benzeyen verileri belli kavramlar ve temalar çerçevesinde bir araya getirmek ve bunları anlaşılabilir bir düzene sokarak yorumlamaktır (Yıldırım ve Şimşek, 2005: 227). Nitel çözümlemede verilerin içeriklerini keşfetmeye yönelik çözümleme için kodlama ilk ve aslî bir işlemdir (Punch, 2005: 193).

İçerik analizinde çalışmalar aşağıdaki işlem basamaklarına göre yürütülmüştür. İlk önce öğretmen adaylarından alınan ve birden başlanarak numaralandırılmış kayda değer veriler tek tek bulguların yazıldığı tablolara işlenmiştir. Daha sonra tablolara işlenen veriler içerik analizine tabi tutulmuştur. Analizde, verilerden hareketle kodlama yapılmış, kodlardan hareketle temalara ulaşılmaya çalışılmıştır. Analizin son aşamasında verilen kod ve ulaşılan temalar üzerinden çıkarım, tanımlama, yorum ve tartışmalar yapılmıştır.

Araştırmada elde edilen veriler, kişisel bilgilerle ilgili olan veriler ve araştırma konusu bağlamında görüşme formu ile elde edilen veriler şeklinde tasnifi yapılarak ayrı ayrı analiz edilmiştir. Kişisel bilgilerle ilgili verilerin analizi kapsamında öğretmenlerin cinsiyet, mezun oldukları eğitim kurumu ve öğretim programı değişkenlerine göre sahip olunan kişisel bilgilerle ilgili verilerin tanımlayıcı analizi yapılarak frekans ve yüzdelik dağılımları verilmiştir. Görüşme formları ile elde edilen verilerin analizi işlemlerinde aşağıdaki kodlama ve tanımlama tekniği kullanılmıştır. 
$\mathrm{A}_{1}, \mathrm{~A}_{2}, \mathrm{~A}_{3} \ldots:$ : Araştırmacının sorularını,

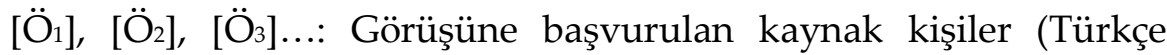
öğretmenleri) ve bu öğretmenlerin kayda değer cevaplarından oluşan kelime, cümle ya da paragrafın numarasını göstermektedir.

\section{BULGULAR}

\section{1. Kişisel bilgilerle ilgili bulgular}

Tablo 1: Öğretmenlerle İlgili Kişisel Bilgiler

\begin{tabular}{lcc}
\hline Öğretmenlerinin Cinsiyetlerine Göre Dağılımı & $f$ & $\%$ \\
Bayan & 8 & 66.67 \\
Bay & 4 & 33,33 \\
Toplam & 12 & 100.00 \\
\hline Öğretmenlerin Meslekî Kıdemleri & $f$ & $\%$ \\
$1-5$ yıl & 1 & 8.33 \\
$6-10$ yıl & 4 & 33,33 \\
$11-15$ yıl & 4 & 33,33 \\
$16-20$ yıl & 2 & 16.67 \\
21 yıl ve üzeri & 1 & 8.33 \\
Toplam & 12 & 100.00 \\
\hline Mezun Olunan Eğitim Kurumu (Fakülte) & $f$ & $\%$ \\
Eğitim Fakültesi & 5 & 41.67 \\
Fen - Edebiyat Fakültesi & 7 & 58.33 \\
Dil ve Tarih, Coğrafya Fakültesi & - & - \\
Toplam & 12 & 100.00 \\
\hline Mezun Olunan Bölüm / Öğretim Programı & $f$ & $\%$ \\
Türkçe Öğretmenliği & 3 & 25.00 \\
Türk Dili ve Edebiyatı Öğretmenliği & 1 & 8.33 \\
Türk Dili ve Edebiyatı & 7 & 58.33 \\
Almanca / Fransızca Öğretmenliğ̀i & 1 & 8.33 \\
İngiliz / Fransız Dili ve Edebiyatı & - & - \\
Dilbilim & - & - \\
Toplam & 12 & 100.00 \\
\hline
\end{tabular}

Tablo 1'de de görülebileceği Araştırmaya 8 bayan ve 4 erkek öğretmen katılmıştır. Mesleki kıdeme göre öğretmenlerin çoğunluğu 6 - 15 yıl kıdem aralığında yer almaktadırlar. Öğretmenlerin beşi Eğitim Fakültesi yedisi de Fen - Edebiyat Fakültesi mezunudur. Eğitim Fakültesi mezunu öğretmenlerin üçü Türkçe öğretmenliği, biri Türk Dili ve Edebiyatı Öğretmenliği, biri de Almanca öğretmenliği mezunudur. Fen-Edebiyat Fakültesi Türk Dili ve Edebiyatı mezunu öğretmen sayısı ise yedidir. 


\section{2. Görüssme Formları İle Elde Edilen Bulgular Analizi Görüşme Sorularıyla Elde Edilen Verilerin Nitel Yaklaşımla İçerik}

A1: Öğrencilerin yazılı anlatım becerileri metne dayalı anlama-kavrama soruları, dil bilgisi konu, kavram ve kuralların ölçen dil bilgisi soruları ile yazılı anlatım becerilerini değerlendirmeye yönelik kompozisyon sorusunun birlikte sorularak tek sınav yapılmasını nasıl değerlendiriyorsunuz?

Olumlu buluyorum. Çünkü metin soruları ve metne dayalı dil bilgisi vb. birbirleriyle ilintili [Ö${ }_{1}$ ]. Metne dayal anlama-kavrama sorular,, dil bilgisi konu, kavram ve kuralların ölçen dil bilgisi soruları ile yazılı anlatım becerilerini değerlendirmeye yönelik kompozisyon sorusunun birlikte sorulması öğrenciler açısından zor oluyor [ $\ddot{\mathrm{O}}_{2}$ ]. Anlama, dil bilgisi ve kompozisyon sorusunun birlikte sorulması uygulamasın doğru buluyorum. Yeni programa göre de bunlarm hepsinin iç içe olması gerekiyor. Ayrıca bir kompozisyon veya dil bilgisi dersi işlemiyoruz [ $\left[\mathrm{O}_{3,6}\right]$. Olumlu değerlendiriyorum. Bütünlük içerisinde hareket ediliyor. Öğretilen bütün kuralları uygulatmış oluyoruz [Ö 4 ]. Kompozisyon sorusunun ayr uygulanması ayrı değerlendirilmesi elbette daha doğru ama daha fazla zaman gerektirir [Ö̈]. Olumsuz buluyorum. Kompozisyon sorularn ayrn bir sinav şeklinde, daha uzun bir sürede yapılmalı ve değgerlendirilmelidir [Ö̈]. Tek sinav yapılabilir ama sinav süresinin ayarlanması gerekir [Ö̈]. Belirttiğiniz sınav metodu uyguladığımız bir metot. Ancak, soruları öğrencilerin seviyelerine uygun ve süreyi göz önüne alarak hazırlamak gerekiyor. Kompozisyon için ayrı bir sınav yapılsa daha iyi olur [Ö10]. Yazllılarda istediğimiz kompozisyonlar çoğu kez amacına uygun olmuyor. Aslında özellikle kompozisyon çalışmalarının ayrı değerlendirilmesi ve bu çalışmalar üzerinde ayrıntılı durulması gerekir. Çünkü beş ders saati yetmediğinden kompozisyon çalışmalarına da ă̆ırlık veremiyoruz [Ö̈11]. Öğrenciler çoğunlukla kompozisyonu yetiştiremediklerinden şikâyetçiler. Ben öğrencilerin fikri yaratıcılıkların daha iyi görebilmek için kompozisyondan ayrı yazıl yapabilecek bir sistem oluşturulmasını istiyorum [Ö̈12].

Verilen cevaplardan da görülebileceği gibi öğretmenlerin 5’i kompozisyon sınavlarının anlama-kavrama ve dil bilgisi sorularıyla birlikte sorularak sınav yapılmasını olumlu bulmaktadırlar [Ö 
Öğretmenlerden 5'i de Türkçe sınavı içerisinde sorulan kompozisyon sorusunun bu sınav kapsamından çıkarılarak ayrı yapılmasını istemektedirler $\left[\ddot{O}_{5,7,10,11,12]}\right.$.

A2: Türkçe yazll sinavlarda anlama-kavrama ve dil bilgisi sorularıla kompozisyon sorusuna verilen sürenin yeterli olduğunu düşünüyor musunuz? (Sonda: Öğrencilerin yazılı anlatım becerilerinin değerlendirilmesi için ayrı bir kompozisyon sinavr yaprlsa daha iyi olabilir mi?)

Süre genelde yeterli. II. kademede ayr bir kompozisyon sinavn yapılmasının gerekli olmadığg düşüncesindeyim [Ö̈, 3]. Soruları hazirlarken bu sürede cevaplanabilecek sorular ya da anlatimlar seçmeye çalışıyoruz. Buna rağmen yetiştiremeyen öğrenciler oluyor $\left[\ddot{\mathrm{O}}_{2}\right.$, 11]. Sürenin yeterli olduğunu düşünüyorum. Yine de kompozisyon sınav ayrı olabilir $\left[\ddot{\mathrm{O}}_{4}\right]$. Süre yeterli değil ama öğrenciler alıştılar. Kompozisyon sınavı ayrı olsa iyi olurdu [Ö 5 ]. Aslında süre biraz kısıtlı oluyor. Diğer sorularnn kısa sürede cevaplanabilir nitelikte hazırlanmasıly do ğal olarak kompozisyon sorusuna zaman kalıyor [Ö̈6. 40 dakika süreli ayrı bir sınav yapılsa ölçme ve değerlendirme daha verimli olur. Onun için kompozisyon stnavı ayrı yapılmalı [Ö̈]. Süre yeterli değil. Bundan dolayı kompozisyon için ayrıca sınav yapılabilir. Böyle olursa öğrenciler daha iyi değgerlendirilir [Ö8, 9]. Mevcut biçimde yaptığımız sınav formatında süre asla yeterli değil. Kompozisyon, beş-on dakika içerisinde özensizce yazılan bir çalışma olmamalıdır [Ö̈10]. Öğrenciler sürenin yetmeyeceği kaygısindan dolayı yazılarında tasvir, benzetme, karşllaştırma, gözlemlerden faydalanma gibi düşünceyi geliştirme yollarına ve öyküleyici anlatım gibi anlatım biçimlerine başvuramadıklarını, daha çok açılamaya dayalı ve birbirini tekrarlayan ifadelerin oluşturduğu yazılar yazmaktadırlar. Bu durumdan dolayı da yaratıcl, zengin içerikli yazılar yazamıyorlar. Kompozisyon sinavinin ayri yapilması bur durumda mantıkl görünüyor [Ö̈22].

Araştırmacının $A_{2}$ kodlu sorusuna öğretmenlerin verdikleri cevaplara bakıldığında birkaç öğretmen $\left[\ddot{O}_{1}, 3,4\right]$ sürenin yeterli olduğunu söylemelerine karşın araştırmaya dâhil edilen öğretmenlerin tamamına yakını sürenin yeterli olmadığını vurgulamışlardır. 
$A_{3}$ : Öğrencilerin yazılı anlatım becerilerini değerlendirmek için yazılı sinavlarda sorulan kompozisyon sorularından başka ölçme aracı kullanmakta mısınız? Cevabınız evet ise neleri kullandığınız konusunda açıklayıcı bilgi verebilir misiniz? (Sonda: Alternatif öğrenci ürünleri: öğrenci portfolyo ürünleri, duvar gazetesi ve sinıf panosunda sergilenen öğrenci ürünleri, performans ve proje çalışmaları dokümanları...)

Evet. Belirlenen bir kitabı belli bir süreçte okuma ve bundan stnav yapma; performans görevi olarak okunan bir kitabı verilen inceleme planı çerçevesinde yazılı olarak sunma, afiş hazırlama vb. çalı̧̧malar yapıyorum [Ö̈1]. Öğrencilerin anlatım becerilerini ders içi etkinlikler kapsamında yapılan yazılı anlatım çalışmaları ile değerlendiriyorum $\left[\ddot{\mathrm{O}}_{2}\right]$. Evet. Kitap okuma formları, sinuf gazetesi çalışmaları, proje çalışmaları, performans görevleri ile öğrencilerin yazma becerilerini değerlendiriyorum $\left[\ddot{O}_{3,6}\right]$. Evet. Günlük ve anı yazdırıyorum. Hikâye özeti yazdırıyorum. Araştırma ödevi veriyorum [Ö 4 ]. Yaratıcı öykü yazma gibi proje ve performans görevleri veriyorum [Ö$\left.{ }_{5}\right]$. Kontrollü yazma, güdümlü yazma, serbest yazma, metin tamamlama, özet çıkarma, metinden hareketle farkh türde metin oluşturma vb. etkinlikler yaptırıp bunları ders içi performansta değerlendirmekteyim [Ö̈]. Her konuda mutlaka yazıl anlatım etkinliği var. Bu etkinliklerde başarılı bulduğum çalı̧̧malar için ilgili öğrencilerin ders içi performans notunu yüksek tutuyorum [Ös]. Yazılı sinavdakinden başka öğrencilerin yazılı anlatım becerilerini ölçmede başka araçlar kullanıyorum. Sinff panosundaki ürünler, performans görevi ve proje çalışmaları, ürün dosyası kontrolü gibi çalışmalarla değerlendirme yapıyorum... [Ö9, 12]. Kompozisyon sorusunu şiir/resim yorumlama, kitap özeti ve okunan kitapların özetini yazma gibi farkl içerikte soruyorum [Ö̈10]. Araştırma ödevleri ile ilgili biriktirdikleri dokümanlarn değerlendiriyorum [Ö̈11].

Verilen cevaplardan da görülebileceği gibi en az bir farklı ölçme aracı da olsa öğretmenlerin tamamı sinavlardaki kompozisyon sorusundan başka öğrencilerin yazılı anlatım becerilerini farklı araçlarla ölçüp değerlendirmektedirler.

A: Öğrencilerin yazılı anlatım becerilerini değerlendirirken kompozisyon değerlendirme ölçütleriniz nedir? 
Başlık, plan, tertip-düzen, konuya uygunluk [Ö̈1. Anlatım (konuyu anlama ve örnekleme) 10 puan. Plan (olayları stralama, bütünlük...) 5 puan. Tertip (yazının düzgünlüğü, kâğıt düzeni) 5 puan. Imlanoktalama 5 puan. Düşüncede özgünlük 5 puan [Ӧ̈2]. Başlık, paragraf düzeni. Buluş-örnekleme-konuya yaklaşım. Anlatım gücü. Planlı yazma. Yazım ve noktalama [Ö̈3]. Kâğıt düzeni, yazı güzelliği, imlâ ve noktalama, içerik. Konuya günlük hayattan örnekler verilmesi. Kendi cümlelerinden oluşan örneklerin verilmesi [Ö 4 ]. Başlık, girişgelişme-sonuç bölümlerine yer verip vermediği; yazı, imlâ ve noktalama işaretleri. Düzgün ve anlaml cümleler kurabilme... [Ö̈]. Başlık, plan, içerik, imlâ-noktalama, yazı... [Ö6]. 30 puan üzerinden değerlendirdiğimizde; başlık, paragraf düzeni 4 puan; ifade, anlatım gücü 8 puan; Buluş, örnekleme, konuya yaklaşım 8 puan; imla, noktalama 6 puan; kâğıt düzeni, yazı 4 puan [Ö7]. Anlama, anlatım, imlâ ve noktalama, başlık ve yazı düzgünlü̈̆̈̈ [Ö̈, 9]. Başlık (5 puan), sayfa düzeni (5 puan), imla-noktalama (5 puan), paragraflar-anlatım gücü- (15 puan) [Ö10]. Konu hâkimiyeti, düşüncelerin yazıya dökümü, yazı karakteri, imla ve noktalama kurallarına uygunluk [Ö${ }_{11}$. Plana uygunluk, uygun başlık bulabilme, düşünceyi geliştirme tekniklerinin kullanımı, uygun anlatım biçimlerini seçme, anlatımın açık, anlaşılır ve örneklerle zenginleştirilmiş olması, paragraflar arası uygun geçişler yapabilme... [Ö̈12].

Verilen cevaplardan da görülebileceği gibi öğretmenler, öğrencilerin yazılı anlatım çalışmalarını ortak bir değerlendirme ölçütüne göre değerlendirmemektedirler. Tüm öğretmenlerin öğrenci çalışmalarında aradığı temel nitelik plan, yazının düzgünlüğü, kâğıdın tertip-düzeni, yazım ve noktalama gibi biçime yönelik özelliklerdir.

$A_{5}$ : Öğrencileri yazılı anlatım çalışmalarını değerlendirme biçiminiz nasıldır? (Sonda: 'Yazılı kâğıtlarında tüm öğrencilerin kompozisyon çalışmalarını diğer sorularda olduğu gibi soru bazında ve her öğrencinin o soruya verdiği cevabı tek tek ve art arda bütünlük oluşturacak şekilde değerlendiririm.' 'Her öğrencinin tüm dokümanlarını toplar öğrenci bazında toplu değerlendirme yaparım.', 'Ürün ürün değerlendirme yaparım.' vb.) 
Öğrenci ürünlerini bütünlük içinde toplu değerlendiririm [Ö${ }_{1}$. Değerlendirmelerim öğrenci bazındadır. Ürün ürün değerlendirme yaparım $\left[\ddot{\mathrm{O}}_{2,}, 7,8,9\right]$. Yazılı kâğıtlarında tüm öğrencilerin kompozisyon çalışmalarım soru bazında değerlendiririm. Ancak dönem sonlarında tüm dokümanlarn toplar, inceler ve yazıl anlatım becerisini değerlendirme formunu doldururum $\left[\ddot{\mathrm{O}}_{3}\right]$. Tek tek okuyarak ve inceleyerek değgerlendiririm [Ö̈]. Diğer sorularda olduğu gibi soru bazında ve her ögrrencinin o soruya verdiği cevabı tek tek ve art arda bütünlük oluşturacak şekilde değerlendiririm... [Ö̈5, 6]. Yazıllda kompozisyon çalışmalarını her öğrencinin yazdığı kompozisyonu tek tek ve art arda bütünlük oluşturacak şekilde değerlendiririm. Yazll harici dokümanlarda ise öğrenci bazında toplu değerlendirme yaparm [Ö$\ddot{10}_{10}$. Yazllıları okuduktan sonra öğrencilere ait diğer dokümanları değerlendiririm [Ö̈11]. Öğrencinin yazll sorularına verdiği cevapların tümünü bireysel olarak değerlendiririm [Ö$\left.{ }_{12}\right]$.

Öğretmenlerin çoğu, yazılı sinavlarda sorulan kompozisyon sorusunu değerlendirirken öğrenci bazında (her öğrencinin anlamakavrama ve dil bilgisi sorularının cevaplarıyla birlikte içi içe) değerlendirme yapmaktadırlar. Üç öğretmen yazılı sınavlardaki soruları soru bazında değerlendirdiğini belirtmiştir. Öğretmenler diğer öğrenci çalışmalarını da dönem sonunda ve toplu olarak değerlendirmektedirler.

A6: Yazılı anlatım becerilerini değerlendirmede kullandığınız öğrenci çalışmaları üzerinde düzeltme sembollerini kullanıyor ve gerekli açıklamaları not ediyor musunuz?

Hayır kullanmıyorum. Çünkü öğrenci sembollerin anlamını bilmiyor... [Ö̈]. Öğrencilerin yazılı anlatım becerilerini değerlendirirken hataların kırmızı kalemle gösterir, düzeltirim. Yazının altına da gerekli notları düşerim $\left[\mathrm{O}_{2}\right]$. Öğrencilerin yazılı anlatım becerilerini değerlendirirken düzeltme sembollerini kullanırım. Gerekli yerlere notlar düşerim [ Ö$_{3}$ ]. Gerekli açıklamaları not ediyor ve çocuklara kâ̆ğıtların gösterip hataların görmelerini sağhlyorum. Çünkü aynı yanlışı yapmamalarını istiyorum [Ö 4 ]. Genellikle kullanırım... $\left[\ddot{O}_{5}, 8,9, \quad 11\right]$. Düzeltme sembolleri kullanırım... [Ö̈]. Sembollerin tamamını bütün öğrencilerde kullanamıyorum, sadece sembolleri algilayabilen öğrencilerde kullanıyorum. Gerekli açıklamaları genellikle yapıyor ve açıklamalarda 
verimi gözleyebiliyorum [Ö̈]. Kullanmıyorum, ancak kâ̆ğıtların üzerine not alıyorum. Sinav sonrası öğrencilere yanlışları hakkında bilgi veriyorum $\left[\ddot{\mathrm{O}}_{10,12}\right]$.

Verilen cevaplardan da görülebileceği gibi 4 öğretmen $\left[\ddot{O}_{5}, 8,9,11\right]$ 'genellikle kullanırım'; 4 öğretmen [Ö${ }_{1,3,10,12]}$ 'kullanmıyorum' derken 4 öğretmen de düzeltme sembollerini kullanmadıklarını ancak öğrenci hatalarını göstererek gerekli açılamaları not ettiklerini belirtmiştirler.

A7: Öğrenci çalışmaları üzerinde yaptığınız açıklamalarla koyduğunuz düzeltme sembollerini görmeleri için öğrencilere çalışmalarını dağıtıyor musunuz?

Kâğıtları dağıtıyorum... gerekirse yanlışları açıklıyorum [Ö̈, 2]. Gerek yazılı kâğıdı gerekse diğer çalışmalarda öğrenci çalışmalarını kendilerine dağıtarak hataların görmelerini sağlarım $\left[\ddot{O}_{3}\right]$. Evet $\left[\ddot{O}_{4}\right.$, 9]. Dağıtırım... [Ö̈5]. Genellikle dağıtırım... [Ö̈6]. Yaptı̆̆gm tüm yazılı anlatım çalışmalarım yazılılar dâhil öğrencilere dağıtır, yanlışların görmelerini sağlarım. Bunun yapıcı etkilerini yıllardır görmüşümdür. Öğrenci-öğretmen güveninde bunun vazgeçilmez

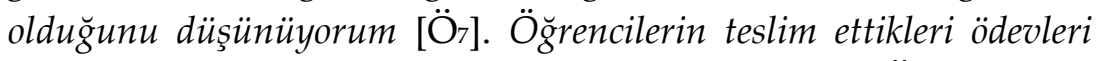
inceledikten sonra tekrar öğrenciye geri veriyorum [Ös]. Yanıma çağırıp gösteriyorum. Öğrencileri tek tek çă̆ırıp en belirgin hatalarını göstermek daha etkili [Ö10]. Ödevleri dă̆ıttığım hâlde yazll kâ̆̆ıtlarımı her zaman dağıtamıyorum. Öğrenci kitlesi de bu konuda önemli. Yanlışların görmek ve anlamak istemeyen o kadar çok öğrenci var ki! [Ö11]. Kesinlikle evet. Öğrenciye eksikliklerini mutlaka göstermeliyim diye düşünüyor ve sonraki adımlarda daha dikkatli olması için gerekli paylaşımlarda bulunuyorum [Ö̈12].

Verilen cevaplardan da görülebileceği gibi görüşüne başvurulan öğretmenlerin tamamına yakını öğrencilerin yazılı anlatım çalışmaları ile ilgili ürünler üzerinde yaptığı düzeltmelerle ilgili sembol, işaret ve açıklamaları görmelerini için genellikle öğrencilere dağıttıklarını belirtmişlerdir. Bir öğretmen, 'Yanıma çağırıp gösteriyorum. Öğrencileri tek tek çağıııp en belirgin hatalarını göstermek daha etkili.' şeklinde cevap vermiştir. 


\section{TARTIŞMA VE YORUM}

Araştırmada görüşüne başvurulan öğretmenlerin yarısı [Ö̈, 2, 3, 4, 6] araştırmacının $A_{1}$ kodlu sorusuna kompozisyon sinavlarının anlamakavrama ve dil bilgisi sorularıla birlikte sorularak sınav yapılmasını yönünde diğer yarısı $\left[\ddot{O}_{5}, 7,10,11,12\right]$ da kompozisyon sorusunun Türkçe sınavlarından çıkarılarak ayrı yapılması yönünde görüş belirtmişlerdir. Türkyılmaz (2008: 12), yazılı sinavların kullanımı konusunda yaptığı bir araştırmasında şu sonuçlara ulaşmıştır: Öğretmenler Dil ve Anlatım dersi yazılı sınavlarında kompozisyon yazdırmaya yönelik soru sormayı tercih etmemektedirler. Öğretmenlere göre öğrenciler anılarını, tanık oldukları bir olay karşısındaki duygu ve düşüncelerini yazdırmaya yönelik soruları tercih etmemekte, atasözü veya özdeyiş açıklamaya yönelik sorular kullanılmaktadır. Ayrıca, kompozisyon konusunun belirlenmesinde öğrencilerin istekleri de etkili olmamaktadır.

Öğretmenlerin öğrenme ve öğretme sürecinde yazılı sınavlarda sorulan kompozisyon sorularından başka portfolyo, performans ve proje çalışmaları dokümanları gibi alternatif öğrenci ürünlerini ölçme aracı olarak kullanmaları gerekir. Bu uygulama öğrencilerin yazılı anlatım becerilerinin sürece yayılmış biçimde ve çoklu değerlendirme araçlarıyla değerlendirilmesinin bir gereğidir. Temizkan'ın Türkçe Öğretmenlerinin Yazılı Anlatım Etkinliği Çerçevesinde Yaptıkları Uygulamaların Değerlendirilmesi başlıklı çalışmasında yazılı anlatım çalışmalarına not verirken öğretmenlerin \% 63,3'ü Türkçe sınavları çerçevesinde yazdırılan kompozisyonları kullandıkları bulgusuna ulaşmıştır (2007: 144). Türk Eğitim Derneğinin 2009 yılında yaptırdığı Öğretmen Yeterlikleri adlı araştırmanın Öğrenmeyi, Gelişimi İzleme ve Değerlendirme Yeterlikleri adlı bölümünde "öğretmenlerin kendi değerlendirmelerine göre \% 62'sinin portfolyoları, \% 61'inin derecelendirme ölçeklerini, \% 54'ünün de kavram haritalarını hiç kullanmadıkları görülmüştür" şeklinde araştırma sonucuna yer verildikten sonra şu şekilde bir değerlendirmede bulunulmuştur: Öğretmenler yenilenen programların gerektirdiği alternatif ölçme ve değerlendirme araçlarını kullanmada yetersiz kalmaktadırlar (TED, 2009: 28). Görüşüne başvurulan öğretmenler araştırmacının $A_{3}$ kodlu sorusuna, yazılı sınavlarda sorulan kompozisyon sorularından başka öğrenci portfolyo ürünleri, duvar gazetesi ve sinıf panosunda sergilenen öğrenci ürünleri, performans ve proje çalışmaları dokümanları gibi alternatif 
öğrenci ürünlerinin oluşturduğu çoklu değerlendirme araçlarıyla sürece yayılmış bir değerlendirmenin yapıldı̆̆ını göstermektedir.

Araştırmacının $A_{4}$ kodlu "kompozisyon değerlendirme ölçütleriniz nedir?" sorusuna öğretmenlerin çoğu başlık, plan, yazının düzgünlüğü, kâğıt düzeni, imla-noktalama, paragraf düzeni, yazı karakteri vb. biçimsel niteliklere değerlendirmede önem verdikleri; bunun yanında buluş, örnekleme, konuya yaklaşım, düşüncede özgünlük, anlatım gücü, konu hakimiyeti, düşüncelerin yazıya dökümü, geliştirme tekniklerinin kullanımı, uygun anlatım biçimlerini seçme, paragraflar arası uygun geçişler yapma ve anlam bütünlüğü gibi içeriğe yönelik niteliklere fazla önem vermedikleri anlaşılmaktadır. Clay (1993) ve Smith (1994), yazmanın (içeriğe yönelik) iki temel işlevinin önemini vurgulamaktadırlar: düşünceleri, verilmek istenen mesajı düzenleme (kompozisyon) ve yazıya geçirme. Bu, mesajın görünebilir bir metin haline getirilme işidir. Arıcı ve Ungan'ın öğrencilerin yazılı anlatımda yaptıkları hataları tespit etme amacıyla yaptıkları araştırmada öğrencilerin büyük çoğunluğunun $(\% 78,9)$ imla yanlışı yaptığı, yarıya yakınının $(\% 45,9)$ noktalama hatası yaptığ görülmüştür (2008: 324). Öğretmenlerin yazım ve noktalamaya çok fazla önem vermelerine rağmen öğrencilerin en fazla hatayı da bu alanda yapıyor olmaları dikkat çekicidir. Ayrıca, ilköğretim ikinci kademe Türkçe Öğretim Programında yazma becerisine yönelik 6 temel amaç (yazma kurallarını uygulama, planlı yazma, farklı türlerde metin yazma, kendini yazılı olarak ifade etme, kendi yazdıklarını değerlendirme, yazım ve noktalama kurallarını uygulama) ve 42 kazanım bulunmaktadır (MEB, 2006). Yazım ve noktalama kurallarını uygulama genel amacına yönelik kazanımlar sadece 2'dir. Programdaki bu dağılıma göre öğretmenlerin kompozisyon çalışmalarında yazım ve noktalamaya gereğinden fazla önem verdikleri ve dolayısıyla diğer kazanımları ihmal ettikleri söylenebilir. Bu durumun Perl ve Sommers adlı araştırmacıların şu görüşleriyle örtüşmektedir: Anlamı keşfetme süreciyle sürekli bir müdahale içerisinde olan biçime gereğinden fazla ilgi göstermek yeteneksiz yazarların işidir. Çalışmaları düzeltmek ve düzenlemek için başvurulan ham ve katı girişimler kompozisyon sürecinin akışını bozmaktadır (Perl ve Sommers, akt. Zamel, 1982: 198). Tüm öğretmenlerin öğrenci çalışmalarında aradı̆̆ temel nitelik, içerik özelliklerinden çok plan, yazının düzgünlüğü, kâğıdın tertip-düzeni, yazım ve noktalama gibi biçime yönelik özelliklerdir. 
Temizkan'ın Türkçe Öğretmenlerinin Yazılı Anlatım Etkinliği Çerçevesinde Yaptıkları Uygulamaların Değerlendirilmesi başlıklı çalışmasında öğretmenlerin \% 63,3'ü öğrencilerin yanlışlarını altını çizerek belirttiklerini söylemişlerdir. Temizkan bu uygulamanın sakıncalarını şu şekilde açıklamıştır: Bu şekilde öğrenciler altı çizili yerlerde hangi yanlışları yaptıklarını ve bu hataların nasıl düzeltilmesi gerektiğini öğrenememektedirler (2007: 144-146). Bu araştırmada görüşüne başvurulan öğretmenlerin çoğu $A_{6}$ kodlu soruyu, "Yazılı anlatım becerilerini değerlendirirken öğrenci çalışmaları üzerinde düzeltme sembollerini kullanıyorum" şeklinde cevaplandırmış olması olumlu bir uygulama olarak değerlendirilmektedir. Ancak öğretmenlerce değerlendirmesi yapılan öğrenci çalışmalarına bakıldığında söylem ile eylemin örtüşmediği de görülebilmektedir (bkz. EK 2a, EK 2b ve EK 2c).

Öğretmenler, öğrencilerin yazılı anlatımlarını sadece not vermek için değil, yazma becerilerindeki sorunlarını tespit etmek ve yanlışlarını düzeltmelerine yardımcı olmak için değerlendirmelidir. Bunu sağlamak için öğretmenlerin geri bildirimlerde bulunmaları çok önemlidir (Coşkun, 2007: 53). Gül (2007: 29), bu konuda şunları söylemektedir: Öğrencilerin yazdıkları yazıların mutlaka değerlendirilmesi, başarılı yönlerinin takdir edilip hatalı yönlerinin düzeltilmesi öğrenciyi yazmaya isteklendirecektir. Dönüt ve düzeltme etkinliklerinin özellikle yazılı anlatım çalışmalarında etkisi büyüktür. Öğrencileri yaptıkları hataları bu şekilde görerek tekrarına engel olacak, olumlu bulunan niteliklerini de görmesiyle daha üst düzey bir anlatım becerisine sahip olabilecektir. Temizkan (2008: 50) da düzeltme, dönüt verme ve değerlendirme aşamasını yazılı anlatımın vazgeçilmez bir parçası olduğunu belirtmektedir. Türk Eğitim Derneğinin 2009 yılında yaptırdığı Öğretmen Yeterlikleri adlı araştırmanın Öğrenmeyi, Gelişimi İzleme ve Değerlendirme Yeterlikleri adlı bölümünde “öğretmenlerin yaklaşık \% 40'1 öğrencilerin ödev ve alıştırma gibi çalışmalarını düzenli olarak kontrol etmediklerini ve geri bildirim sağlamadıklarını belirtmiştir. Öğrencilerin \% 73'ü öğretmenlerinin ödev, proje ve benzeri çalışmaları kontrol ettiğini, ancak öğretmenlerinin \% 66'sının ödev, proje ve benzeri çalışmaları ile ilgili doğru, eksik ya da yanlışlar konusunda kendilerine bildirmediğini belirtmişlerdir (TED, 2009: 28). $A 7$, sorusuna öğretmenlerin verdikleri cevaba bakilınca dönüt ve düzeltmeye yeterli önemi verdikleri anlaşılmaktadır. 


\section{SONUÇ VE ÖNERILER}

\section{1. Sonuçlar}

Araştırmaya dâhil edilen öğretmenlerin yarısı kompozisyon sınavlarının Türkçe sınavı içerisinde anlama-kavrama ve dil bilgisi sorularıyla birlikte yapılmasını olumlu bulmaktadırlar. Öğretmenlerin yarıdan fazlası ise Türkçe sınavlarında kompozisyon için verilen sürenin yeterli olmadığını, bundan dolayı Türkçenin haftalık ders saati sayısının artırılarak kompozisyon sınavının ayrı yapılmasını istemektedirler.

Öğretmenlerin çoğu -en az bir farklı ölçme aracı da olsasinavlardaki kompozisyon sorusunun yanında öğrencilerin yazılı anlatım becerilerini farklı araçlarla değerlendirmektedirler.

Öğretmenler, öğrencilerin yazılı anlatım çalışmalarını ortak bir değerlendirme ölçütüne göre değerlendirmemektedirler. Dikkat ettikleri temel ölçütte içerikten çok biçimsel nitelikler öne çıkmaktadır.

Öğretmenlerin çoğu, öğrencilerin yazılı anlatım çalışmalarını değerlendirirken çalışmalarla bütünleşik ve sürece yayılmış değerlendirme yerine toplu değerlendirme yapmaktadırlar.

Öğretmenlerin yarıdan fazlası düzeltme sembollerini hiç kullanmamaktadırlar. Kullandığını belirten öğretmenlerin de çoğu öğrenci ürünleri üzerinde yaptığı düzeltmelerle ilgili sembol, işaret ve açıklamaları görmelerini için genellikle öğrencilere dağıtmaktadırlar.

Türkçe öğretmenleri gerek etkinlikleri yerli yerince gerçekleştirmede gerekse öğrenci başarısının belirlenmesinde hem zaman hem de uygulama biçimi konusunda sıkıntı içerisinde olduklarını belirtmektedirler.

\section{2. Öneriler}

İlköğretim ikinci kademesinde Türkçenin haftalık ders saati sayısı artırılmalı, gerek etkinlik gerçekleştirme ve inceleme çalışmaları konusunda gerekse kompozisyon sınavının Türkçe sınavları içerisinden çıkarılarak müstakil bir kompozisyon sınavı yapmaları konusunda öğretmenlere hareket serbestisi tanınmalıdır. Kompozisyon çalışmalarının ayrı bir sınavla değerlendirilmesi durumunda İlköğretim 6,7 ve 8 . Sınıf Türkçe Programının önerdiği 100 puan üzerinden değerlendirme ölçeği kullanılabilir (bkz. EK 1a). 
Öğrencilerin yazılı anlatım becerileri değerlendirilirken sadece yazılı sinavlarda sorulan kompozisyon sorusu ile yetinilmemeli; öğrenci portfolyo ürünleri, duvar gazetesi ve sinıf panosunda sergilenen öğrenci ürünleri, performans ve proje çalışmalarıyla ilgili dokümanlar gibi tüm öğrenme ve öğretme sürecini kapsayan alternatif öğrenci ürünlerinin de değerlendirilmesi sağlanmalıdır.

Millî Eğitim Bakanlığı öğrencilerin yazılı anlatım çalışmalarının değerlendirilmesinde kullanılmak üzere önerdiği ölçütlerin tüm öğretmenlerce etkin bir şekilde kullanılması için gerekli önlemleri almalı. $\mathrm{Bu}$ şekilde öğretmenlerin öğrencilerin yazılı anlatım çalışmalarını ortak bir değerlendirme ölçütüne göre değerlendirmesi sağlanmalıdır. Öğrencilerin kompozisyon çalışmalarının değerlendirilmesinde yazının güzelliği, kâğıdın tertip ve düzeni gibi şekle yönelik niteliklerin not dağılımındaki değeri düşürülmeli, bunun yanında düşünceyi geliştirme yollarına başvurma, uygun anlatım biçimlerini seçme, anlatımın açık, anlaşılır ve örneklerle zenginleştirilmiş olması, paragraflar arası uygun geçişler yapabilme ve anlam bütünlüğü oluşturma vb. içeriğe yönelik niteliklere daha fazla önem ve değer verilmelidir.

Öğretmenler, sadece yazılı sınavlardaki kompozisyon sorularının karşılığı olarak yapılan çalışmalarla öğrencileri yazılı anlatım becerilerinin ölçülemeyeceğini bilmelidirler. Tek bir ölçme aracına bağlı kalınarak değerlendirme yapma yerine öğrencilerin yazılı anlatım yeterliklerini alternatif ölçme araçlarından oluşan çoklu değerlendirme araçları ile değerlendirme yapılmalıdır.

Öğrencilerin gerek yazılı sinavda yazdıkları kompozisyonların gerekse tema kapsamında gerçekleştirilen etkinliklerle yazdıkları metinler değerlendirildikten sonra öğrencileri mutlaka geribildirim verilmelidir. Öğrencilerin yazılı anlatım becerilerinin kusursuz hale getirilmesinde dönüt ve düzeltme çalışmaları ihmal edilmemelidir.

Yazılı anlatım, sözlü anlatıma göre daha zor kazanılan bir beceridir. Yazılı anlatımda uyulması gereken birtakım kurallar vardır. Anlatılmak istenen duygu, düşünce, hayal, izlenim ya da tasarılar bu kurallar çerçevesinde dile getirilir. Bu bakımdan ilköğretim Türkçe derslerinde dört temel dil becerisinden en zor olan ve en son kazanilan yazma becerisine daha fazla önem verilmelidir. İlköğretimde kazandırılan yazma becerisi devam eden eğitim kademelerinde de geliştirilmeye çalışılmalıdır. Öğrenimlerini tamamlayan bireyler sosyal hayata atıldıklarında 
duyduklarını, düşündüklerini, hayal ettiklerini rahat bir şekilde ifade edebilir durumda olmalıdırlar. Çünkü iyi yazı yazabilen meramını etkili bir anlatımla dile getiren bireylerin, günlük yaşamlarında da düzenli, ilkeli, ölçülü ve başarılı olacakları muhakkaktır.

\section{KAYNAKLAR}

Arıcı, A. F. \& Ungan, S. (2008). İlköğretim II. Kademe öğrencilerinin yazılı anlatım çalışmalarının bazı yönlerden değerlendirilmesi. Dumlupınar Üniversitesi Sosyal Bilimler Dergisi, 20, 317-327.

Clay, M. M. (1993). Reading recovery: a guidebook for teachers in training. Portsmouth, NH: Heinemann.

Coşkun, E. (2009). Yazma eğitimi (ss. 49-91), İlköğretimde Türkçe Öğretimi (Editörler: Ahmet Kırkkılıç \& Hayati Akyol, 2. Baskı). Ankara: Pegem Akademi.

Emig, J. (1971). The composing process of twelfth graders. Urbana, IL: National Council of Teachers of English.

Göçer, A. (2005). Illköğretim ikinci kademe Türkçe öğretiminde ölçme ve değerlendirme (Yayımlanmamış Doktora Tezi). Erzurum: Atatürk Üniversitesi Sosyal Bilimler Enstitüsü.

Göçer, A. (2009). Türkçe öğretiminde ölçme ve değerlendirme (ss. 375-416), Ilköğretimde Türkçe Öğretimi (Editörler: Ahmet Kırkkılıç \& Hayati Akyol, 2. Baskı). Ankara: Pegem Akademi.

Göçer, A. (2010). Eğitim fakültesi öğrencilerinin yazılı anlatım becerilerinin süreç yaklaşımı ve metinsellik ölçütleri ekseninde değerlendirilmesi (Niğde Üniversitesi Örneği). Kastamonu Üniversitesi Kastamonu Ĕ̆itim Dergisi. 18 (1), 271-290.

Gül, P. (2007). İlköğretim öğrencilerinin yazılı anlatım becerilerinin geliştirilmesi. İlköğretmen, 5, 28-29.

Hillocks, G. J. (1987). Synthesis of research on teaching writing. Educational Leadership, May 1987, 71-82.

MEB (1970). Devlet ortaokul türkçe imtihan soruları. 1611 Sayılı Tebliğler Dergisi. İstanbul: Millî Eğitim Bakanlığı Basımevi.

MEB (1973). Ortaokullar (Türkçe Dersi) Kompozisyon imtihanları 1747 Sayılı Tebliğler Dergisi. İstanbul: Millı̂ Eğitim Bakanlığı Basımevi. 
MEB (2006). Illö̈̆rretim Türkçe dersi (6, 7 ve 8. Sinıflar) öğretim programı. Ankara: Millî Eğitim Bakanlığı Talim ve Terbiye Kurulu Başkanlığı.

Murray, D. M. (1980). Writing as process: how writing finds its own meaning. In T. R. Donovan and B. W. McClelland (Eds.) Eight Approaches to Teaching Composition. Urbana, IL: National Council of Teachers of English.

Okurer, C. (1967). Kompozisyon öğretimi bakımından ingiltere maarifi hakkında bir inceleme (Neticeler ve Bazı Teklifler). İstanbul: Millî Eğitim Basımevi.

Punch, K. F. (2005). Sosyal araştırmalara giriş: nitel ve nicel yaklaşımlar (Çevirenler: D. Bayrak, B. Aslan \& Z. Akyüz), Ankara: Siyasal Kitabevi.

Skandalaris, L. (1998). Teaching for strategies in writing: maintaining the balance between composing and transcribing. The Running Record, $10(2), 1-12$.

Smith, F. (1994). Writing and the writer. $2^{\text {nd }}$ ed. Hillsdale, New Jersey: Lawrence Erlbaum Associates.

Taylor, B. P. (1981). Content and written form: A Two-Way Street. TESOL QUARTERLY, 15 (1), 5-13.

TED (2009). Öğretmen yeterlikleri - özet rapor. Ankara: Türk Eğitim Derneği Yayınları.

Temizkan, M. (2007). Türkçe öğretmenlerinin yazılı anlatım etkinliği çerçevesinde yaptıkları uygulamaların değerlendirilmesi. Millî Ĕ̆itim, 174, 135-154.

Temizkan, M. (2008). Türkçe ve sınıf öğretmeni adaylarının yazılı anlatım çalışmalarını düzeltme ve değerlendirme durumları. Ahi Evran Üniversitesi Kırşehir Eğitim Fakültesi Dergisi (KEFAD), 9 (3) 49-61.

Türkyılmaz, M. (2008). Dil ve anlatım dersinde bir ölçme aracı olarak yazılı sınavların kullanımı konusunda öğretmen görüşleri. Ahi Evran Üniversitesi Kırşehir Ĕ̆itim Fakültesi Dergisi (KEFAD), 9 (3) 1-14.

Witte, S. P. \& Lester, F. (1981). Coherence, cohesion and writing quality. College Composition and Communication, 32 (2), 189-204.

Yıldırım, A. \& Şimşek, H. (2005). Sosyal bilimlerde nitel araştırma yöntemleri (5. Bask1). Ankara: Seçkin Yayıncılık. 
Zamel, V. (1982). Writing: the process of discovering meaning. TESOL QUARTERLY, 16 (2), 195-209.

Ek 1a: Yazılı Anlatımı Değerlendirme Formu (MEB, 2006: 231) Öğrencinin Adı ve Soyadı: Sınıfı: Nu.:

\begin{tabular}{|c|c|c|c|}
\hline $\begin{array}{l}\text { Ölçüt } \\
\text { Alanı }\end{array}$ & $\begin{array}{l}\text { Yazılı anlatımda aranacak } \\
\text { özellikler }\end{array}$ & \begin{tabular}{|c||} 
Verilmesi \\
gereken \\
puan
\end{tabular} & Öğretmenin vereceği puan \\
\hline \multirow[t]{2}{*}{ Biçim } & $\begin{array}{l}\text { Kâğıdın kenarlarında, paragraf ve } \\
\text { satır aralarında uygun boşluklar } \\
\text { bırakılmıştır. }\end{array}$ & 5 & \\
\hline & $\begin{array}{l}\text { Düzgün, okunaklı ve işlek bir yazı } \\
\text { kullanılmıştır. }\end{array}$ & 5 & \\
\hline \multirow{9}{*}{$\begin{array}{l}\text { Dil ve } \\
\text { Anlatım }\end{array}$} & Başlık konuyla ilgilidir. & 5 & \\
\hline & $\begin{array}{l}\text { Konu, mantıksal tutarlılık ve } \\
\text { bütünlük içinde anlatılmıştır. }\end{array}$ & 5 & \\
\hline & $\begin{array}{l}\text { Paragraflar arasında uygun geçiş } \\
\text { sağlanmıştr. }\end{array}$ & 5 & \\
\hline & $\begin{array}{l}\text { Her bir paragrafta tek bir duygu ve } \\
\text { düşünce işlenmiştir. }\end{array}$ & 5 & \\
\hline & $\begin{array}{l}\text { Yazıda verilmek istenen ana fikre } \\
\text { ulaşılmıştr. }\end{array}$ & 10 & \\
\hline & $\begin{array}{l}\text { Ana fikir ve duygu, yardımcı } \\
\text { fikir ve duygularla } \\
\text { desteklenmiştir. }\end{array}$ & 10 & \\
\hline & $\begin{array}{l}\text { Alıntı, örnek ve benzetmeler } \\
\text { yeterli olup içeriğe uygundur. }\end{array}$ & 10 & \\
\hline & $\begin{array}{l}\text { Sonuç ifadesi konuyu bağlayıc ve } \\
\text { etkileyicidir. }\end{array}$ & 5 & \\
\hline & $\begin{array}{l}\text { Cümle kuruluşları dil bilgisi } \\
\text { kurallarına uygundur. }\end{array}$ & 5 & \\
\hline
\end{tabular}




\begin{tabular}{|c|c|c|c|}
\hline & $\begin{array}{l}\text { Kelimeler yerinde ve doğru } \\
\text { anlamda kullanılmıştır. }\end{array}$ & 5 & \\
\hline & $\begin{array}{l}\begin{array}{l}\text { Cümlede kelime tekrarları } \\
\text { yapılmamıştr. }\end{array} \\
\end{array}$ & 5 & \\
\hline & $\begin{array}{l}\text { Konuyla ilgili kaynaklara } \\
\text { başvurulmuş ve yeterince } \\
\text { yararlanılmıştır. }\end{array}$ & 5 & \\
\hline & $\begin{array}{l}\text { Konuyu kendine özgü } \\
\text { ifadelerle anlatmıştır. }\end{array}$ & 5 & \\
\hline \multirow{2}{*}{$\begin{array}{l}\text { Yazım ve } \\
\text { Noktalama }\end{array}$} & $\begin{array}{l}\text { Yazıda yazım kurallarına } \\
\text { uyulmuştur. }\end{array}$ & 5 & \\
\hline & $\begin{array}{l}\text { Noktalama işaretleri doğru } \\
\text { yerde kullanılmısțr. }\end{array}$ & 5 & \\
\hline
\end{tabular}

NOT: Ölçekte belirtilen puanlama örnek olarak verilmiştir. Öğretmen tarafından değiştirilebilir.

Ek 1b: Yazma Becerisi Değerlendirme Ölçeği (Göçer, 2005: 241)

\begin{tabular}{||l||c||c||}
\hline \multicolumn{1}{|c|}{ ÖLÇÜTLER } & \multicolumn{2}{c||}{ PUANLAMA } \\
\cline { 2 - 3 } & $\begin{array}{c}40 \text { puanlık } \\
\text { bir } \\
\text { kompozisyon } \\
\text { sorusu için }\end{array}$ & $\begin{array}{c}100 \text { puanlık bir } \\
\text { kompozisyon } \\
\text { sorusu için }\end{array}$ \\
\hline $\begin{array}{l}\text { Plan fikri (başlık, giriş, gelişme, sonuç; } \\
\text { yazının güzelliği, sayfa düzeni) }\end{array}$ & 7 puan & 17,5 puan \\
\hline \hline $\begin{array}{l}\text { Olaylara bakış açısı; duygu, düşünce, } \\
\text { gözlem, izlenim ve tasarılardan } \\
\text { yararlanma }\end{array}$ & 8 puan & 20 puan \\
\hline \hline $\begin{array}{l}\text { Anlatımda duruluk ve doğallık; kelime ve } \\
\text { cümle bilgisi }\end{array}$ & 10 puan & 25 puan \\
\hline \hline $\begin{array}{l}\text { Konuyu anlama, orijinal örneklerle } \\
\text { açıklama; paragraflar arası anlam } \\
\text { bütünlüğü }\end{array}$ & 9 puan & 22,5 puan \\
\hline \begin{tabular}{l} 
Yazım ve Noktalama \\
\hline \hline TOPLAM
\end{tabular} & 6 puan & 15 puan \\
\hline \hline
\end{tabular}


EK 2a. Öğretmenlerce Değerlendirilen Öğrenci Yazılı Anlatımı Çalışması Örneği

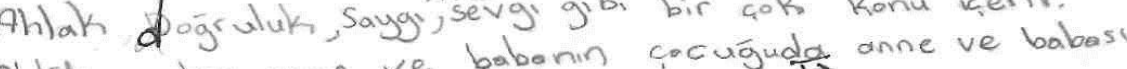
Ahlaksiz bir anne ve babonin cocuguada

gibi ahlaksiz dur. Bu kisi büyüklerine saygi kücuklerine sevgi gibi Athläk Kelimesini iceren kantardan kaçiniv. Ahtakl, bir kisi temiz olmalidir Temiz dmadigi halde Sik sik hasta olabilir/Ahtaki bir Kisiñomer insanlar

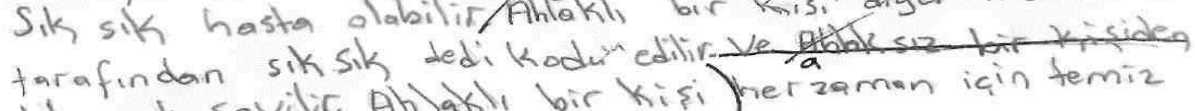
daba cok sevitir Ahiakil bir kisi) berzaman icin temiz
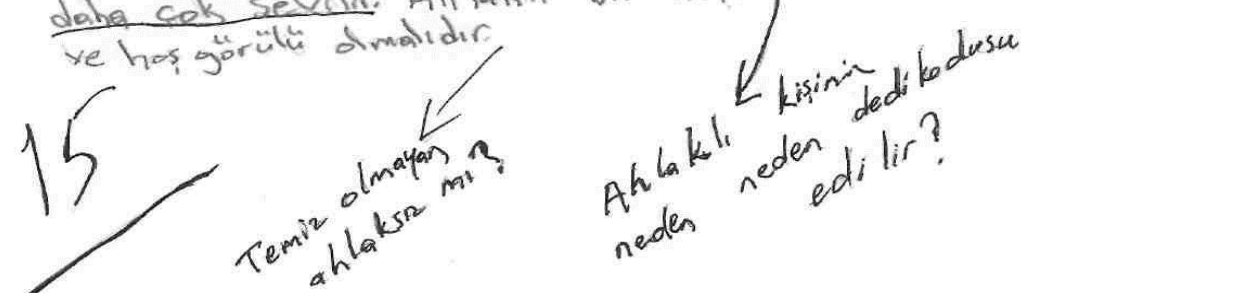

EK 2b. Öğretmenlerce Değerlendirilen Öğrenci Yazılı Anlatımı Çalışması Örneği

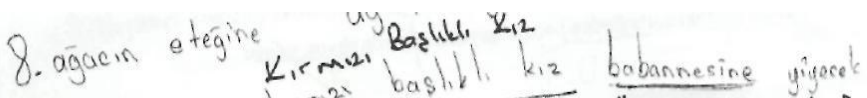

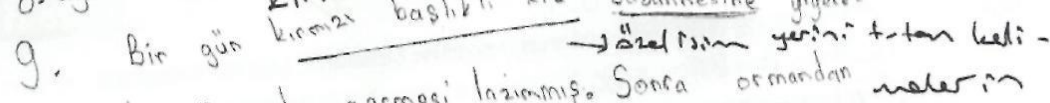

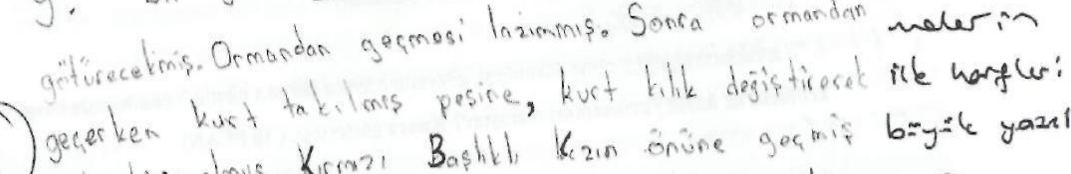

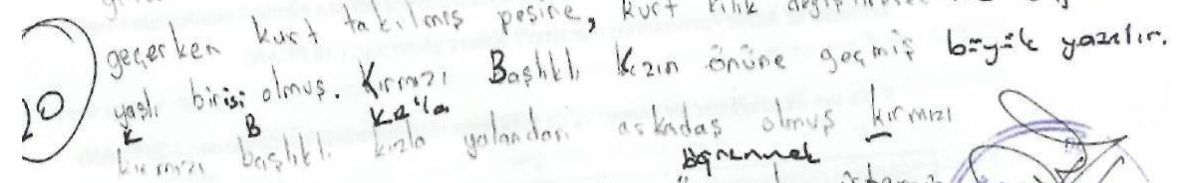

bashlli kizer, babannesinin evini örenmek

ve örenmif. Kirmm bastlli kizden one

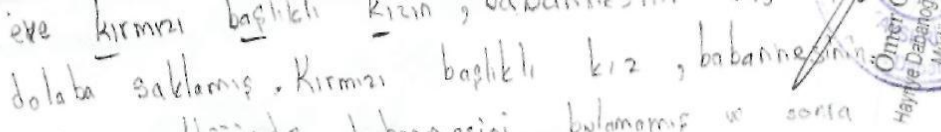

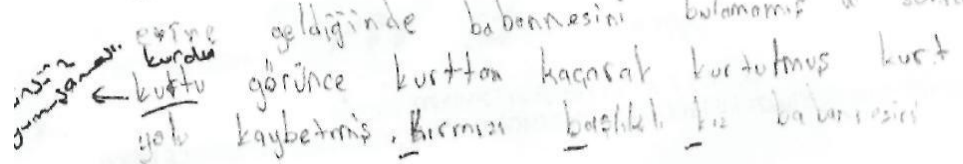

kurtarms. 
EK 2c. Öğretmenlerce Değerlendirilen Öğrenci Yazılı Anlatımı Çalışması Örneği

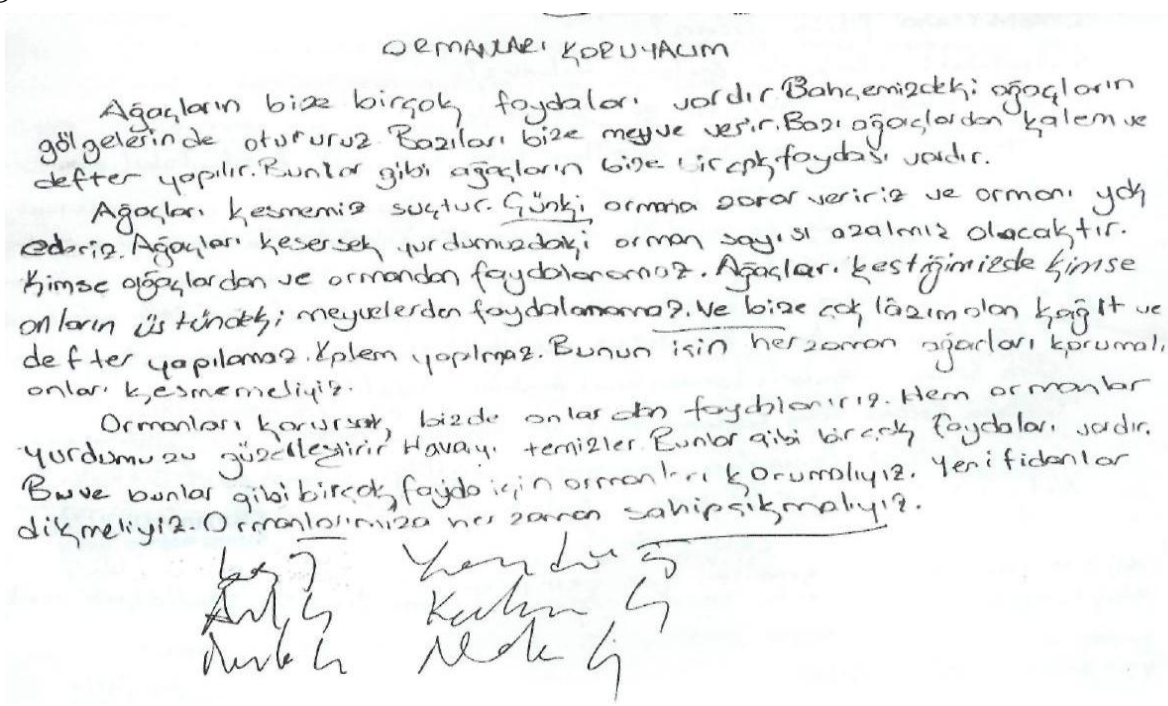

\section{EXTENDED ABSTRACT}

\section{PURPOSE OF THE RESEARCH}

The aim of this study is evaluation of written expression studies to determine methods and techniques used by Turkish teachers.

\section{METHOD}

\section{1. Research Model}

In this study, interviewing and document review methods within the framework of qualitative research were used.

\section{2. Universe and Sample}

The population of this study is the Turkish teachers in primary schools in the district of Kayseri-Melikgazi. Six of the schools in this district were stratification sampling method. The sample consists of 12 Turkish teachers working in schools identified. In addition, activity in the Turkish teachers 
applied for review of their written works and written examination papers for review were determined in samples.

\subsection{Limitations}

This research, interviewed 12 Turkish teacher, interview used to collect data in the form of 7 (seven) interview questions and teachers' answers to the interview questions, applied to documents written examination papers written for the event data is limited.

\section{4. Data Collection and Analysis}

Basic data collection tool was prepared, The Semi-Structured Interview Form. The Semi-Structured Interview Form was first of all applied by two Turkish teachers and was finalized in line with the responses received from the interview form. Later, the interview form consisted of 7 (seven) questions directed to the 12 Turkish teachers. The data obtained with interview form were analyzed by content analysis. Other documents were examined with the scanning technique.

The main objective of qualitative data analysis is to examine the meaningful and symbolic content of the qualitative data collected (Ekiz, 2009). Content analysis involves collecting similar data within the framework of certain concepts and themes, putting them into a conceivable order and subsequently interpreting them (Yıldırım \& Şimşek, 2005). In qualitative analysis encoding in is a primary and essential process for sorting out and exploring the content of the data (Punch, 2005).

Content analysis studies were conducted according to the following steps: First the data (findings) obtained from the interview forms were recorded. Then they were processed into chapter and the data were subjected to content analysis. After the analysis of data, coding was done and then categorized according to themes. Finally comments and discussions were made through the identification codes and themes.

The data on teachers' personal information (gender, professional experience, graduates from which educational institutions / training 
programs) underwent descriptive analysis by frequency and percentage distributions.

In the analysis of the data obtained from interview forms;

$\mathrm{A}_{1}, \mathrm{~A}_{2}, \mathrm{~A}_{3} \ldots .$. Defines the questions of the researcher,

$\left[\ddot{O}^{1}\right],\left[\ddot{\mathrm{O}}^{2}\right],\left[\ddot{\mathrm{O}}^{3}\right] \ldots$ : Defines the reference people whose opinions have been taken (Turkish teacher).

\section{FINDINGS}

\section{1. Findings related to personal knowledge}

Eight female and four male teachers participated in the study. Looking at the distribution of teachers according to seniority there was 6-15 year range of seniority. The teachers who participated in the research, included 5 from the School of Education / Faculty of Education, and four of them were graduate Turkish teachers and 7 teachers from the Faculty of Arts and Science, and all of them were Turkish Language and Literature graduates.

\section{2. Findings obtained from interview forms}

Nearly half of teachers' comprehension-comprehension and grammar questions to be asked the question of the composition and making with a single exam is positive side $\left[\ddot{O}_{1,2,3,4,6}\right.$. More than half of the teachers want to be made a separate Turkish exam and essay exam. [Ö̈, 7, 10,11,12].

Almost all of the teachers included in the survey indicated that not enough time.

All of the teachers, at least one other addition to the question of essay exams even if different tools use different measurement tools.

Teachers, a common criterion in assessing the work of writing do not have.

All the basic qualifications of teachers of students looking for work, the plan, the smoothness of paper, paper-organized layout, spelling and punctuation, such as the properties of the format. 
Most teachers make assessment on the basis of written exams accompanied by the question of the composition. Three teachers stated that evaluates on the basis of written exam questions, questions.

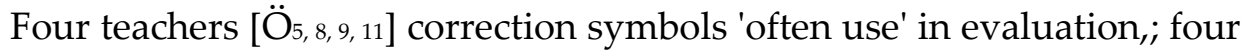
teachers $\left[\ddot{O}_{1,3,10,12]}\right.$ 'Not use' saying, 4 teachers not use the correct symbols, but descriptions of student shouts errors that they stated that the required showing.

Almost all of the teachers consulted, written expression of students on work-related products on the corrections, symbol, sign, and to see descriptions of the often stated that students who are displaying. 
ÖĞRENCILERIN YAZILI ANLATIM ÇALIŞMALARININ TÜRKÇE

BU SAYFA BOŞBIRAKILMIŞTIR. 